River based on the 1866 yield as 100 per cent. The comparative yields of each crop, considering the 1866 crop as 100 per cent., were calculated. These percentages were weighted according to the area planted to the crop in order to secure a percentage representing the yield of that year.

G. F. WARREN

CORNELL UNIVERSITY

\section{STANFORD UNIVERSITY MEDICAL SCHOOL}

Dr. Victor O. Vaughan, dean of the department of medicine and surgery of the University of Michigan, has made, under date of June 9,1914 , the following report to Dr. J. C. Branner, president of Leland Stanford Junior University :

In compliance with your telegraphic request I have visited Palo Alto and San Francisco and inspected the libraries, laboratories and hospitals of Stanford University. The laboratories of chemistry (general, physical, inorganic, organic and physiological), biology, histology, neurology and physiology are well housed, adequately equipped and exceptionally well manned. In all these, high grade work is being done. The laboratories of bacteriology and anatomy need better housing and I understand that this is to be provided in the near future. But in the buildings now occupied, most excellent work is being done. In fact each of the scientific departments at Stanford is under the direction of an eminent man supplied with able and enthusiastic assistants and with necessary equipment. There is abundant evidence even in a hasty inspection that the appropriations have been economically and wisely expended and that good work is being done both in instruction and in research. I wish to compliment the trustees and president upon the evident wisdom which they have displayed in the development of these departments of the university. What I have said of the scientific branches is equally true of the other departments of Stanford University. Although one of the youngest of the higher institutions of learning in this country Stanford ranks as one of the best in all departments, both scientific and humanistic. In all branches it represents the highest aims and ideals. While $\mathrm{I}$ am not fitted to express anything more than a general opinion as to other than scientific education I wish to emphasize the fact that all learning is one and the same spirit should pervade the whole. This I believe to be true at Stan- ford. It furnishes a wholesome atmosphere in which the student ean grow whatever special line of training he may follow later. The greatest need of our country is the man whose fundamental knowledge is broad and comprehensive and whose special training is exact. No man can have useful knowledge of a part unless he has general knowledge of the whole. The working of the part must be in harmony with the movements of the whole; otherwise disaster is the result. While I am especially interested in medical education, I recognize the fact that it is futile to try to develop a good medical man out of one whose fundamental training has not been sound. The young man who has learned to work with the right spirit, whether it be in Greek or biology, in philosophy or chemistry, will enter medicine, law or any profession in the right frame of mind and will be likely to prove an honor in his chosen profession. In his preliminary college training the prospective medical student should not be confined to the physical or biological sciences. It is desirable that he know the classics, history and philosophy and it is most desirable that the training that he gets along these lines should be of the highest grade. I believe that Stanford University furnishes suitable conditions for the development of the young man who is going into medicine. Therefore $I$ hope that the medical work done at Palo Alto may continue. If the medical school should be closed, this would relieve Stanford of only one of the laboratories at Palo Alto. Physics, chemistry, biology, physiology, histology, embryology, neurology and bacteriology must be taught and research work in these branches must be done in a university of the high rank Stanford holds. Closing the medical school would give only trifling financial relief to the university. I therefore recommend that the premedical and medical work now done at Palo Alto be not only continued but be developed as fast as the finances of the university permit. I make this recommendation not only for the good of the medical school, but, as I believe, in the interest of the university as a whole. If the medical department should be discontinued, anatomy is the only subject which could be dropped at Palo Alto and even then this should not be done. Anatomy is one of the great and fundamental biologieal sciences and even human anatomy should be taught in a great scientific university. Anatomy is no longer tanght as a mere foundation for medicine and surgery. It includes the development of structure from the lowest to the highest forms of life. 
I went to San Franciseo and made an inspection of the library, hospital and laboratories of the medical school.

The Lane library is one of the best medical libraries in the country. It is supplied with practically all the best medical journals so arranged as to be most available to members of the faculty and students. Its location in regard to the hospital and laboratories is quite ideal. It is worth much to both the clinical and the research man to have at his hand the best contributions of the world. When a problem comes up for solution the first thing to learn is to ascertain what has already been done along this line. A medical school without a library is like a boat without a pilot and much time is likely to be lost in drifting. The medical department of Stanford is fortunate in the possessing of its library.

While the present hospital building is somewhat out of date it is, so far as I can see, admirably managed both in caring for the sick and in the instruction of students. The out-patient department, systematized as it is, is both a great, broad and needful charity and at the same time a source of varied and comprehensive instruction to students. The addition soon to be made to the hospital will modernize the institution. It will bring more pay patients to the institution and thus furnish the funds with which the less fortunate can be cared for. I was greatly pleased with the management of the hospital. The laboratories in the hospital are ably conducted and fairly well equipped. Some of them will probably have enlarged and improved quarters when the addition is made to the hospital.

As I understand the total cost of the medical department is now about one hundred thousand dollars per year. This cost will slowly increase. Notwithstanding this fact I strongly urge that the medical school be not only continued but be developed. In its development the quality of its work should be constantly held in mind. The number of medical students should be kept small. Quality and not quantity should be the aim. I believe that in the near future the medical department will be a source of strength to the university in many ways. First, in the importance of the research done and the benefits that such research will confer on the race. Within the past thirty years the average human life has been increased nearly fifteen years and the whole of life has been made more comfortable. This is a work to which a great university should contribute. The open- ing of the Panama Canal will bring to the Pacific coast many health problems which can be best solved in such a school of instruction and research as I believe Stanford will develop. Second, I am firm in the belief that the medical school will attract large donations, both for research and the clinical work. Philanthropists will see that the best service they can render lies in the direction of improved health conditions. Third, medicine is now attracting to its ranks many of the best of our young men and this will be a source of strength to the university.

Lastly, I come to the matter on account of which I was called to visit you. The time may come when it may be wise to consolidate the two university medical schools of San Francisco, but I do not believe that this would be wise at present. Stanford, from what I can learn, can afford to develop its medical school without material hindrance in the growth of other branches and I believe that this is the wise thing to do.

I am aware of the fact that a hasty visit, such as I have made, may give erroneous impressions and I would not have you attach any great importance to this report, but I have tried to look at matters from a broad viewpoint and to hold constantly in mind the good of Stanford University as a whole. I have considered it unnecessary to go into financial or other details with which you are much more familiar than I am.

In conclusion I wish to thank you, ... and Dr. Wilbur and other members of your faculty for the many courtesies shown me and to express the hope that the growth of Stanford University during the past quarter of a century, phenomenal as it has been, may be surpassed in its future developments.

With great respect, I am Yours most respectfully,

\section{C. VAUGHAN}

\section{NEWTON HORACE WINCHELL}

The tribute I can render to the late Professor Winchell must be such as would quite spontaneously come from any one who had watched, with appreciation and sympathy, the progress of geological science in America during the past generation. I can not speak of Professor Winchell from a close personal intimacy, but I may, as one of many who highly regarded his very unusual achievements in one science and his broad, effective interest in sev- 